\title{
Cameroonian responses to COVID-19 in the education sector: Exposing an inadequate education system
}

\section{Emmanuel Béché ${ }^{1}$}

Published online: 31 October 2020

(c) UNESCO Institute for Lifelong Learning and Springer Nature B.V. 2020

\begin{abstract}
This article presents and interprets Cameroonian responses to COVID-19 in the education sector. The four main challenges the Cameroonian educational authorities found themselves facing at the onset of the pandemic were (1) how to ensure continuity of formal education; (2) how to minimise exacerbation of already existing educational inequalities; (3) which tools to choose for ensuring continuity; and (4) how to enable pupils and students at exam stage to progress to the next level of their academic career. To collect relevant data for his analysis of how these challenges have been addressed, the author used three tools: documentary analysis, interviews, and digital observation of distance learning platforms. His findings form a detailed panorama of educational responses to COVID-19 in Cameroon. These include institutional, community and individual initiatives, ranging from paper-based materials to distance learning platforms, TV and radio communication tools. The implementation of these approaches, however, has revealed that the Cameroonian education system is plagued by disorganisation, educational inequalities and exclusion - problems which affect learners' daily lives on a personal level. The structural and pedagogical deficits revealed by the findings of this study demonstrate that Cameroon must insist on two things if it wants to guarantee educational normality in the event of other similar crises, namely (1) integrating distance-learning technologies; and (2) improving access to essential socio-educational services.
\end{abstract}

Keywords COVID-19 - Cameroon · pedagogical continuity · responses · educational inequality $\cdot$ distance education

\section{Résumé}

Les réponses camerounaises à la COVID-19 dans le secteur de l'éducation: mise à nu d'un système d'éducation inapproprié - Cet article présente et interprète les réponses camerounaises à la COVID-19 dans le secteur de l'éducation. Les quatre principaux défis auxquels les autorités camerounaises en charge de l'éducation se sont vues con-

Emmanuel Béché

beche@beche-emmanuel.com

1 Higher Teachers' Training College, University of Maroua, Maroua, Cameroon 
frontées au début de la pandémie étaient les suivants : (1) comment assurer la continuité de l'éducation formelle; (2) comment atténuer l'exacerbation des inégalités éducatives déjà existantes; (3) quels outils choisir pour assurer cette continuité et (4) comment permettre aux élèves et étudiants sur le point de passer des examens d'évoluer pour passer à la prochaine étape de leur parcours de formation ? Pour recueillir les données utiles à l'analyse de la façon dont ces défis ont été abordés, l'auteur a recouru à trois outils : une analyse documentaire, des interviews et l'observation numérique des plateformes d'apprentissage à distance. Les fruits de ce travail ont produit un panorama des réponses éducatives du Cameroun à la COVID-19, sous forme, entre autres, d'initiatives institutionnelles, communautaires et individuelles allant de matériels sur papier à des plateformes d'apprentissage à distance, en passant par des outils de communication télévisuels et radiophoniques. La mise en œuvre de ces approches, toutefois, a révélé que le système d'éducation camerounais était en proie à la désorganisation, aux inégalités éducatives et à l'exclusion - des problèmes qui affectent le quotidien personnel des apprenants. Les insuffisances structurelles et pédagogiques dévoilées par les résultats de cette étude démontrent que le Cameroun doit insister sur deux choses s'il veut garantir une normalité éducative en cas d'autres crises similaires, à savoir (1) l'intégration des technologies d'apprentissage à distance et (2) l'amélioration de l'accès aux services socio-éducatifs de base.

\section{Introduction}

With more than 320 deaths and almost 15,000 officially confirmed cases as of 6 July 2020 (Coronavirus Statistiques 2020), ${ }^{1}$ Cameroon was among the topmost COVID19-affected countries in sub-Saharan Africa. Nick Routley (2020) pointed out that, as of 12 May 2020, Cameroon was the country with the highest weekly coronavirus infection rate in the world (12\%). The spread of COVID-19 in Cameroon, which began on 6 March 2020, has not left the education sector unscathed: on the contrary, it has had a significant impact on schools (UNESCO 2020) and to a slightly lesser extent on higher education institutions.

Education has been at the heart of the government's strategy for responding to the COVID-19 pandemic. The strategy set out by the Prime Minister on $17 \mathrm{March}$ 2020 placed education as a top priority. Schools and universities were ordered to lock down, and face-to-face academic activities were suspended. To compensate for the cessation of "live" teaching, the Ministries of Basic Education, Secondary Education and Higher Education decided, after two weeks of hesitation, to continue courses by using distance teaching and learning tools. The government also recommended that school and university administrators should prioritise the use of distance communication tools for meetings, seminars and conferences. The paralysis of the education sector caused by the onset of the COVID-19 pandemic, occurring in the middle of the academic year, meant that all Cameroonian learners were suddenly

\footnotetext{
${ }^{1}$ In the context of the ongoing COVID-19 pandemic, it is important to note that this article was drafted in July 2020.
} 
"involuntarily out of school": 4.5 million in primary schools, 1.8 million in secondary schools, 40,000 learners in vocational training, and 347,000 in higher education (UNSDG 2020).

The ministries in charge of education found themselves facing several emergent challenges generated by this crisis, in addition to the existing one of educational inequalities. The gross school enrolment rates in Cameroon are the highest in the Central African subregion: $105.75 \%$ in primary school, $60.06 \%$ in secondary school and $14.3 \%$ in higher education (UIS 2020). However, these statistics hide glaring disparities in terms of access to quality education, from which learners and students from low-income families are largely excluded. School completion rates are poor for girls and rural children in particular, whose exclusion rates are $29 \%$ and $31 \%$ respectively (MINEDUB 2018). Inequalities also exist in terms of Cameroon's geographical distribution of schools, which is unfavourable to the country's three northern regions (Kana 2019; Mouafo Djontu 2013).

Within this unequal context, the first challenge COVID-19 forced the Cameroonian educational authorities to address was that of ensuring pedagogical continuity, both in form and substance (Søndergaard 1995; Bellen 2016). The objective was to continue schooling despite the closure of schools and the confinement of learners and teachers to their homes. The challenge therefore concerned how to maintain the rhythms of the school calendar during the period of disruption (Gaetan 2020). Occurring at the end of the second term for primary and secondary schools and the end of the first semester for tertiary-level students, the COVID-19 outbreak made it very difficult to continue the normal functioning of the school calendar 2019/2020 (Bianchini 2004). It also proved difficult to organise official exams and evaluations in the second semester. Ministers focused on finding ways to establish and strengthen pedagogical links between school and home in order to provide educational continuity despite the disruption (DSDEN de l'Oise 2020). The key question was: How, in a time of crisis and confinement, can we reproduce the learning environment of school within the home, such that courses, resources, interactions and pedagogical approaches continue to function? (Søndergaard 1995; Bellen 2016).

The second challenge is related to educational inequalities, especially since the Education Orientation Law enshrines education as a "major national priority" and a State regal duty, guaranteeing access and equality of opportunity (GoRC 1998). The Ministers of Basic Education, Secondary Education and Higher Education insisted on this challenge in their respective communiqués on the implementation of strategies to fight COVID-19. The challenge is encapsulated in the following question: How, in times of confinement, can we ensure pedagogical continuity through new educational technologies without exacerbating existing educational inequalities? This issue was crucial, since the education sector was not starting from a level playing field: there were already marked disparities in access to educational opportunities between rural and urban areas, well-off and disadvantaged families, and girls and boys before the outbreak of the pandemic. The fact that distance technologies are still weakly and unevenly distributed among the Cameroonian population continues to threaten to widen these disparities further (Mbodiam 2019).

The third challenge concerned the choice of tools for ensuring pedagogical continuity. The search for suitable technological and pedagogical solutions 
proved difficult and time-consuming. More than two weeks after the arrival of COVID-19 in the country, the Ministries of Secondary and Basic Education were still searching for the appropriate technological apparatus with which to complete the 2019/2020 school year. The challenge was to find out which of the various options (radio, television, internet, digital platforms, communication and storage tools) was the most accessible and the most easily manageable in a context of unequal access to communication tools. While the Ministries of Basic Education and Secondary Education were accustomed to using audio-televised classes to help students revise three weeks before their official exams, the COVID-19 crisis required a sudden and vast expansion of the use of such technologies, which was not easy to implement. The issue was how to design virtual "classrooms" via radio and television which would be accessible to all learners and allow teachers to teach rather than simply helping to revise.

The fourth challenge was to safeguard the passage of pupils progressing to higher levels of their school career in the context of confined and distanced schooling, whilst continuing to guarantee educational quality. As Kaliope AzziHuck and Tigran Shmis (2020) wrote in a blog post on 18 March, the impact of COVID-19 on education was expected to be particularly dramatic in countries which already had low learning outcomes, high dropout rates and limited shock resilience before the outbreak of the pandemic. The current pandemic will doubtless prove to have been highly detrimental to learning, given the extent of the pedagogical breakdown it has caused in many African countries, including Cameroon. The impact of COVID-19 on the success and failure of learners thus requires more attention, especially if we consider the disruption it has caused to the educational process, the unequal accessibility of distance learning tools, and the difficulties experienced by both pupils and teachers in adapting to these new tools (UNESCO 2020).

To address these unexpected and exceptional challenges, the three Cameroonian ministries in charge of education set in motion a variety of responses. Whilst online sources such as press releases, communiqués, declarations of intent etc. provide information on the objectives sought and the tools used as part of these responses, little is known about their actual impact and the logic behind their choices. There is no evidence yet regarding the effectiveness of Cameroon's pedagogical continuity mechanisms, because no research has been carried out yet to examine how successful they have been. This article therefore seeks to provide an analytical insight into the responses of the Cameroonian education sector to the COVID-19 pandemic. In so doing, it shines a spotlight on the inherent weaknesses of the education system in this country. My analysis focuses on five main points:

(1) an overview of the education sector's responses to COVID-19;

(2) the implementation of "School on TV";

(3) distance learning;

(4) teaching practices via messaging tools; and

(5) the pandemic's role in exposing the inherent weaknesses of the Cameroonian education system. 


\section{Methodology}

To portray the Cameroonian education sector's responses to COVID-19, I adopted a descriptive approach (De Ketele 1992). This involved listing, reporting and interpreting the technological and pedagogical solutions put in place in response to the crisis (Doury 2013). To access data, I used documentary analysis, interviews and digital observation.

The textual corpus I consulted for the documentary report included official recommendations and operational strategies formulated to ensure pedagogical continuity. From texts released by the Head of Government, the ministries in charge of education and university institutions, I extracted information which described Cameroon's plan for how to deal with the impact of COVID-19 on education. These texts include the special declarations made by the Prime Minister on 17 March, 1 April, 30 April and 15 May 2020 respectively, as well as the decrees, memoranda and communiqués of the Ministries of Basic Education, Secondary Education and Higher Education, and communiqués from the eight State universities. ${ }^{2}$

For the interviews, which were conducted in French, I targeted four resource persons (RPs 1-4) who have been at the heart of the implementation of Cameroonian educational responses to COVID-19. Two of them were involved in distance education at primary and secondary level: a primary school teacher who had presented several lessons within the framework of "School on TV," and a national pedagogy inspector at the Ministry of Secondary Education who had helped to deliver lessons on TV and radio. I also interviewed two other resource persons who provided expertise on distance course delivery, one was a university official who coordinated online courses within his institution, the other was a lecturer who is a specialist in educational technologies. I interviewed these four people via Skype about two main issues: (1) the development of Cameroonian school responses to COVID-19, and (2) their experiences with distance education and online courses.

The digital observation consisted of following the activities of students and teachers on online course platforms. I visited the learning management systems of the University of Ngaoundéré, the University of Dschang, and the Faculty of Science of the University of Yaoundé 1. I also took an interest in WhatsApp ${ }^{3}$ group discussions on teaching and learning during the school lockdown. I integrated WhatsApp groups from selected secondary schools and from the universities of Maroua, Douala and Yaoundé 2, thanks to the teacher administrators of these groups to whom I submitted an access request. In both cases, I examined four key indicators: adoption of distance tools, accessibility, participant interaction and evaluation.

\footnotetext{
${ }^{2}$ Cameroon has eight state universities: Bamenda, Buea, Douala, Dschang, Maroua, Ngaoundéré, Yaoundé 1 and Yaoundé 2.

3 WhatsApp is a smartphone application designed for communication among users who are often part of a WhatsApp group. Thus, one member can send a text or voice message (and/or pictures, documents etc.) to everyone in the group with a single post.
} 
All data collected were examined via content analysis. I identified the occurrence of the words "responses", "prevention" and "precaution" in the text documents ${ }^{4}$ and considered what was meant by them in context. This made it possible to describe the mechanisms implemented by the Cameroonian school system in response to the COVID-19 crisis. I transcribed the interviews and identified sub-themes related to the two main issues flagged above. Although I categorised these sub-themes, I chose not to quantify them, as my intention in the study was merely to describe how schools and universities went about managing COVID-19. The digital observation of online learning platforms was helpful in underpinning my analysis of the data I had extracted from the documents and interviews, especially those concerning the sudden digitalisation of teaching and learning practices.

\section{Seeking solutions to COVID-19-related educational challenges}

Between 6 March 2020, the date of the first confirmed case of COVID-19 in Cameroon, and 17 March 2020, the date of the first government communication on the Cameroonian response to the pandemic, almost a dozen days of silence elapsed. However, on the eve of 17 March, the University of Yaounde 1, on its own initiative, issued a communiqué listing the academic measures it intended to take in response to COVID-19 (CamerounWeb 2020). The University of Yaoundé 1 was therefore the first institution to publicly demonstrate concern about the coronavirus and its impact on education. It is striking that this happened in a context of "presidential silence", where the ears of the population were wide open to hear guidance on the appropriate course of action (Adjouda 2020). This university initiated the lockdown of campuses and the suspension of face-to-face academic activities, and in doing so paved the way for what its Rector called "a radical change in teaching methods by strengthening digital education" (CamerounWeb 2020).

Following the Prime Minister's first communication on COVID-19 on 17 March (SPM 2020), other administrative structures were galvanised into action, as though they had been waiting for the government "referee" to announce "kick-off". One day later, on 18 March, the Minister of Secondary Education initiated a broad consultation to work out how to implement distance education. In a memorandum on "Content of distance education" (MINESEC 2020), she invited regional and departmental delegates, school heads and teachers to send their "excellent courses" (ibid.) to be used for distance schooling. As an extension of this memorandum, the Inspectorate General of Education (IGE) ${ }^{5}$ in turn issued an invitation to teachers on the same day entitled "Fight against coronavirus" (IGE 2020), asking them to "propose solutions that might enable secondary school pupils to continue to receive distance education"

\footnotetext{
${ }^{4}$ Most of the documents I examined were in French, and the French keywords I searched for were "réponses", "prévention" and "précaution". For the purposes of this article, I have also translated all originally French quotations from administrative documents and interviewee's responses into English.

5 In Cameroon, the mission of the Inspectorate General of Education is to elaborate, monitor, evaluate and develop training programmes, didactic tools and pedagogical orientations, policies and innovations. For more information, visit http://www.minedub.cm/index.php?id=18 [accessed 18 October 2020].
} 
within five days (ibid.). At the end of this "national" consultation, the Ministry of Secondary Education adopted television as a means of providing educational continuity, initiating the "School on TV" programme. ${ }^{6}$ A course database platform was also created, ${ }^{7}$ although it was not up and running until a later date.

Schools and teachers were given leeway to implement parallel solutions according to their technical skills and capacities. This led to a proliferation of WhatsApp group discussions, Google Classroom accounts ${ }^{8}$ and online tutoring applications. Although being used within the framework of an institution, in $95 \%$ of cases these tools were implemented on the individual initiative of teachers familiar with these new technologies, particularly computer science teachers (RP 2). The value of individual initiatives in ensuring pedagogical continuity in the era of COVID-19 is also illustrated in the example of Jean Baptiste Essissima, a Cameroonian resident in Canada who designed and launched (on 27 March 2020) an application called SchoolMobile which has been gratefully taken up. Costing EUR 1.50 per course or EUR 15.30 per term, SchoolMobile is an online revision platform for secondary school students in francophone Africa. ${ }^{9}$ It runs on both mobile phones and computers and was already being used by more than 5,000 students by 20 April 2020. Other individual initiatives include actions taken by a number of politicians, public intellectuals and community associations, who organised private lessons for rural students or made printed worksheets and teaching materials available to them. There was therefore a fruitful cooperation between educational institutions and individuals working together to ensure pedagogical continuity.

The Ministry of Basic Education launched the search for alternatives to face-to-face schooling on 31 March 2020, 25 days after the first confirmed case and more than two weeks after the lockdown of school campuses. In a circular "relating to the continuous learning of students", the Minister of Basic Education encouraged regional and departmental delegates, unions and parents to "harmonise" lessons and to engineer a model course to support "School on TV" (MINEDUB 2020). He also invited teachers to provide distance learning using tools such as WhatsApp, Zoom ${ }^{10}$ and mobile phones. Parents were asked to explore the databases of the Avicenna Virtual Campus

\footnotetext{
${ }^{6}$ L'école à la télévision was launched by Cameroon Radio Television (CRTV) on 6 April (Djimadeu 2020). Since Cameroon has two official languages, French and English, this distance learning concept "[took] into consideration the two sub systems of Education. On Mondays, Wednesdays and Fridays", classes were broadcast in French, while classes in English wee broadcast on Tuesdays, Thursdays and Saturdays (Lum 2020).

7 Interested readers can visit the course platform at https://minesec-distancelearning.cm/1.

${ }^{8}$ Google Classroom was created in 2014. It is a free web service for schools designed for creating, distributing and grading assignments.

${ }^{9}$ For more information, visit https://www.schoolmobile.net/about/ [accessed 8 October 2020]..

10 Zoom is a video conferencing platform.
} 
for Science and Technology, ${ }^{11}$ Siyavula, ${ }^{12}$ TESSA $^{13}$ and AbulÉdu, ${ }^{14}$ to guide their children's learning at home (MINEDUB 2020.). However, it was television, via the "School on TV" programme, which was promoted as the main solution. For this occasion, the national broadcasting company, Cameroon Radio Television (CRTV), like France 4 in France, ${ }^{15}$ was transformed into a classroom, during defined time slots.

At university level, the Ministry of Higher Education held a meeting on 20 March, four days after the University of Yaoundé 1's solitary initiative, aiming to harmonise its "strategy" for the implementation of "the strategy prescribed by the government" (MINESUP 2020). The meeting was attended by the eight Rectors of public universities, the Rector of the Pan-African University, the Coordinator of the CameroonCongo Interstate University, the heads of public higher education institutions with special status, two representatives of private university institutions, ${ }^{16}$ and senior officials of the Ministry of Higher Education. At the end of the consultation, a battery of pedagogical continuity measures were selected. In addition to campus lockdowns and the readjustment of university calendars, this set of solutions included the use of learning management systems, electronic messaging tools such as WhatsApp, and teleworking and videoconferencing tools such as Zoom and Skype. The University of Yaoundé 1 centralised all its courses on an online platform. ${ }^{17}$ Other institutions allowed faculty, department and individual initiatives to coexist.

In sum, the search for pedagogical continuity solutions in Cameroon was a "race against time" in a context that had not yet integrated distance technology as an essential training modality. The responses were a patchwork combination of institutional and individual initiatives, learning management systems and information and communication tools.

\footnotetext{
${ }^{11}$ The Avicenna Virtual Campus for Science and Technology was launched by the United Nations Educational, Scientific and Cultural Organization (UNESCO) in November 2002 with funding from the European Commission through its Euro-Mediterranean Information Society (EUMEDIS) programme. It offers courses in French and English at primary, secondary and higher education levels as well as teacher training modules, support in designing distance learning programmes etc. For more information, visit https://unesco.aven.fr/courses/.

12 Based in Cape Town, South Africa, Siyavula (the name is the Nguni word for "we are opening") runs a collaborative free online maths and science textbook project. For more information, see https://www. siyavulaeducation.com/.

13 Teacher Education in Sub-Saharan Africa (TESSA) is "a network of teachers and teacher educators stretching across Sub-Saharan Africa. At the heart of the network is a bank of open educational resources (OER), linked to the school curriculum, and designed to support teachers and teacher educators in developing active approaches to learning. The network is coordinated by the Open University [in England]." (http://www.tessafrica.net/about-us [accessed 20 October 2020]). The resources, in English, French, Arabic and Swahili, can be found at http://www.tessafrica.net/home.

${ }^{14}$.AbulÉdu-fr is an association of teachers, computer scientists, parents of students, retirees and Educational Technology facilitators. Resulting from a project of the same name, it offers free educational resources (in French) at http://abcd.abuledu.org/ and https://abuledu-fr.org/category/ressources-educatives-libres/.

${ }^{15}$ In an effort labelled "opération nation apprenante" [operation learning nation], public television station France 4 started broadcasting lessons for primary school (mornings) and secondary school children (afternoons) on 23 March 2020. The lessons were designed by teachers from the French ministry of education (Barba 2020; RFI 2020).

${ }^{16}$ Cameroon has 235 private university institutes, which accommodate $20 \%$ of the tertiary student population. For more information, visit https://www.minesup.gov.cm/site/index.php/instituts-prives-dense ignement-superieur/.

17 The online course platform of the University of Younde 1 is at http://www.coursuy1.uninet.cm/.
} 


\section{"School on TV": when the television that replaces the teacher comes up against electrical problems}

The Ministries of Basic Education and Secondary Education launched the "School on TV" programme in partnership with CRTV. Particular emphasis was placed on the classes facing examinations: Class six, Form four, Form six and Form seven for French-speaking students; Class six, Form five, Lower six and Upper six for English-speaking ones. ${ }^{18}$ For Class six learners preparing for the Primary School Certificate exam, the programme ran from 8.00 a.m. to 10.30 a.m. every Tuesday, Thursday and Friday. For those preparing for the First School Leaving Certificate exam, which marks completion of lower secondary school, "School on TV" was held on Mondays, Wednesdays and Fridays at the same time. For general and technical secondary education, ${ }^{19}$ the programme was from 9.30 a.m. to 6.00 p.m., Mondays, Wednesdays and Fridays for French speakers, and Tuesdays, Thursdays and Saturdays for English speakers.

The first courses were launched on 6 April 2020. The timetables and programmes were widely distributed and communicated beforehand so that parents and children could make the necessary arrangements for following the courses and taking notes. The operating principle of "School on TV" was as follows: teachers appointed by the national pedagogical inspectorates taught the selected courses using a blackboard and video projection. Learners were asked to sit in front of their TV screens and take notes. The project manager of the "School on TV" programme also specified that the lessons were interactive, meaning that "pupils ha[d] the opportunity to ask questions to teachers by SMS via the number 8018" (Djimadeu 2020). The "School on TV" manager also invited parents to support their children's learning at home by providing them with additional resources in mathematics, language, science and computer science from recommended databases. In practice, however, interaction was mixed. While for RP 1, "SMS messages sent by students from their homes were a guarantee of interactivity and remediation", RP 2 disagreed. For him, it was "impossible to talk about rhythm, progress and interactivity in such a context since the audience was disparate, and the answers to questions were not immediate".

Nevertheless, for the first time in educational history, television became a substitute for school. This is all the more notable when we remember that school and

\footnotetext{
${ }^{18}$ In Cameroon, school education is free (excepting books and uniforms) and compulsory for all children aged 5-11, i.e. until completion of six years of primary school (Classes 1-6). Completion of the primary school cycle is marked by the Certificat d'Etudes Primaires Elémentaires/the Certificate of completion of primary elementary education. Those students whose families can afford the fees progress to lower secondary (or middle) school (Forms 1-4 in francophone schools; Forms 1-5 in anglophone schools). Completion of lower secondary (or middle) school is marked by the Brevet d'Études du Premier Cycle du Second Degré for francophone students and by the General Certificate of Education (GCE) Ordinary Level for anglophone students. Those who continue enter upper secondary school (Forms 5-6 in francophone schools; lower and upper Forms 6 in anglophone schools). Completion of upper secondary school is marked by the Baccalauréat for francophone students and by the GCE Advanced Level for anglophone students. Passing one of these last two exams qualifies them for application to universities.

19 In Cameroon, secondary school is subdivided into two areas: general education and technical education, which are managed by the same ministry, that of secondary education.
} 
television coexisted uneasily for a very long time (Balle 1994, p. 79). Though television teaching programmes had been initiated in some parts of Africa including Cameroon prior to the COVID-19 pandemic, this was the first time in this country's history that pupils had to abandon their classrooms to continue their schooling in a new environment. Although they had the same teachers, these were now virtualised and remote. Instead of voice and non-verbal communication in situ, interactions were mediated by text messaging. While note-taking media like paper notebooks, pencils and ballpoint pens had not changed, other elements of the teaching-learning situation had disappeared to make way for the new tools. Living rooms or bedrooms replaced traditional classrooms; sofas, benches, stools or mats supplanted school desk benches; and siblings and neighbours became casual classmates. In effect, television substituted for teachers, with cameramen choosing the gestures, postures and angles to zoom in on for the students.

Cameroon's unreliable electricity supply posed an additional challenge to "School on TV". According to Brice R. Mbodiam (2019), more than 45\% of Cameroonians do not have access to electricity. Rural areas, which include more than $60 \%$ of the country, are only $21 \%$ covered by the electricity network. Their populations were therefore de facto excluded from "School on TV". Even urban areas are not immune to fluctuations in the electricity supply, whose high rates of load shedding reach the coast in cities such as Douala, Yaoundé and Bertoua (Onana 2020). As Francis Andrianarison and Blaise Ehowe Nguem (2020) write, these electricity deficits have exacerbated educational exclusion and inequality in the age of COVID-19.

"School on TV" was the leading solution for pedagogical continuity in primary and secondary education. Dedicated solely to students in examination classes, however, it excluded those in intermediate classes and those with inadequate access to electricity. In practice, "School on TV" created a learning environment where standard school structures coexisted with or were replaced by those of daily life.

\section{From distance learning to online documents in universities}

In an interview given to CRTV on 20 March 2020 entitled "Can digital technology ensure the continuity of university courses?" (CRTV 2020a), the Minister of Higher Education listed the tools used for this purpose: learning management systems, WhatsApp, e-mail and mobile phones. For distance conferences and meetings, he listed Skype and Zoom. Following this interview, conducted after the consultation meeting of the Ministry of Higher Education held earlier on the same day, academic institutions scrambled to "exhibit" their innovative tools and approaches for maintaining pedagogical and administrative continuity. For example, the University of Yaoundé 1 praised its distance training system built on Moodle, ${ }^{20}$ restarted in the age of COVID-19, in a report on national television on 20 March 2020 (CRTV 2020b). The University of Douala launched a digital university press as well as an

${ }^{20}$ Moodle is an open-source learning platform. 
online course system for each of its fourteen faculties and institutes. ${ }^{21}$ The University of Bamenda, for its part, boasted of its proactivity in setting up a platform for pedagogical interactions. ${ }^{22}$ In a note addressed to the Cultural Service of the United States Embassy in Cameroon (on which I was copied), one of its officials said that the campus lockdown was an opportunity for his university to enhance its distance learning provision. The same is true for the University of Buea ${ }^{23}$ and the Catholic University Institute ${ }^{24}$ located in the same city, whose distance learning programmes have been in place for three years.

The Universities of Ngaoundéré and Maroua stand out in their efforts. The former massively increased the use of its Moodle platform ${ }^{25}$ in all departments, which prior to COVID-19 had only been used in the Department of Geography. The latter, as well as implementing several online training systems using Google Classroom and Forma LMS, ${ }^{26}$ developed a digital environment for distance meetings and thesis and dissertation defence. The University of Maroua is the first university in Cameroon to have organised a viable way of defending doctoral dissertations using the Zoom videoconferencing application. ${ }^{27}$

In many cases, these tools for pedagogical continuity in Cameroonian universities have been used in ways that differ from the original intention. In most universities, courses were centralised on the institutions' online platforms. In practice, however, teachers entrusted their courses and learning activities to the managers of these platforms, who, in turn, made them available to learners. One of my interviewees (RP 4) said that " $80 \%$ of teachers submitted their courses, as a block, in a single file, which could be as long as 50 or even 100 pages". The task of the platform managers was then to upload these files to the spaces dedicated to the corresponding courses so as to make them accessible to students. The platform managers therefore played an intermediary role between teachers and learners. Communication between teachers and students, which in the classroom had taken place directly, was now mediated by two new actors: screens and platform managers. The object of these interactions was mainly the exchange of course files, which led RP 2 and RP 3 to say that, rather than actually being educated online, Cameroonian students were merely being given access to online documents.

\footnotetext{
21 The course portal (in French) at https://www.univ-douala.cm/index.php/acceder-aux-cours provides a hyperlinked overview of these faculties and institutes.

22 Interested readers can visit the University of Bamenda's course platform (in English) at https://uniba onlinelearning.net/.

23 The range of e-learning courses offered by the University of Buea is presented at http://www.uiasb uea.org/e-learning/.

24 The Hybrid Ubiquitous Teaching and Learning platform of the Catholic University Institute of Buea is at https://ubiquitous.cuib-cameroon.org/.

25 The distance learning platform of the University of Ngaoundéré is at https://foad.univ-ndere.cm/.

26 Forma LMS is an open-source, web-based e-learning platform used to manage and deliver online training courses. The University of Maroua's e-learning platform is at http://e-campus.ens.univ-marou a.cm/.

27 For more information (in French), visit http://www.univ-maroua.cm/fr/article/l-uma-lance-sa-serie-desoutenances-de-theses-en-visioconference.
} 
Observing the records of students' activities on the three platforms I targeted, ${ }^{28} \mathrm{I}$ noted that many were downloading course files. When submitting homework files, half of the students opted for a paper format, sometimes at the request of their teachers. Students gathered their homework in boxes, which the class reps then collected and gave to the teachers, in compliance with protective measures, such as using masks and hydroalcoholic gels. Feedback took the same path: teachers - class reps - boxes - students. My observations show that students went to the platforms more to download course materials and carry out related instructions than for other pedagogical tasks. Due to the lack of teacher-student interaction, students were not able to attend synchronous meetings. As RP 4 stated, "there has been a terrible lack of teacher initiatives, which are necessary for pedagogical interactions to take place on the platforms". After courses were posted on the platforms (sometimes by administrators rather than teachers themselves), $90 \%$ of teachers did not provide tutoring or feedback (RP 3; RP 4). This issue reinforces the observation that in distance education, putting resources and courses online is not synonymous with digitised teaching (Peraya 2008).

These shortcomings are largely due to poor digital skills among teachers themselves. The International Telecommunication Union (ITU 2019) states that less than $15 \%$ of Cameroonians command basic digital skills. Teacher-student interaction was also hampered by Cameroon's low internet coverage, which currently stands at $30 \%$ overall and only $4 \%$ for broadband (Mbodiam 2020). While $74 \%$ of Cameroonian households have at least one mobile phone, this is not the case for computers, social network memberships, smartphones and tablets, respectively owned by only $24 \%, 12 \%, 20 \%$ and $2 \%$ of households. The average purchase price of a smartphone in Cameroon is exceedingly high: 50,000 CFA francs (76.22 Euros), well above the minimum wage of 36,270 CFA francs per month. The same is true for mobile data allowances (ITU 2019).

While learning management systems were the primary means of maintaining course continuity in universities, they co-existed with communication tools such as WhatsApp, which tended to distract students from learning, since educational content was forced to compete with personal conversations. While campus lockdowns created an opportunity for universities to praise the originality of their innovations, in practice, these sidelined teachers in favour of IT experts and replaced pedagogical interactions with file exchange.

\section{When messaging tools mingle with pedagogy}

According to an interview with the Minister of Higher Education on 20 March 2020 (CRTV 2020a), mobile phones and WhatsApp were among the tools recommended to ensure the continuity of teaching in Cameroonian universities. These

\footnotetext{
${ }^{28}$ The three platforms were those of the University of Ngaoundére (https://foad.univ-ndere.cm), the University of Dschang (https://fs-elearning.univ-dschang.org) and the University of Yaoundé 1 (http://www. coursuy1.uninet.cm).
} 
communication and messaging tools were chosen not so much for their pedagogical merit as for their ease of use, and because many students already had them. As RP 4 stated, "most teachers are not familiar with distance learning applications such as Google Classroom, Moodle, NEO LMS. ${ }^{29}$ So, we had to make do with what they know best: mobile phone and WhatsApp". According to Kalvin Bahia and Stefano Suardi (2019), mobile phones, including smartphones, are the best-integrated technology in the lives of African student populations.

For this reason, the smartphone has been the most widely used technological support during the lockdown period (aside from the platforms that received the online documents). According to RP 3, more than $90 \%$ of students continued their courses through their smartphones, far ahead of the computer, which was used by less than $10 \%$ of Cameroonian university students. The WhatsApp application was the most widely used platform for exchanging files and educational interactions, which were often drowned in private conversation and everyday life. In all Cameroonian universities, platforms dedicated to training merged with general messaging tools, WhatsApp in particular. This mixing was not only technological; it also affected the content broadcast on WhatsApp. Although WhatsApp groups for particular classes and courses were created, academic files still rubbed shoulders with private files (photos, videos and personal or shared documents). Educational forums were also mixed with non-academic chats. This mix of "lives" was especially pronounced among students who were not yet proficient in creating folders on their smartphones (RP 4). The use of WhatsApp as a training tool during the COVID-19 lockdown therefore meant that academic and everyday life, private conversations and academic exchanges, were inextricably mixed up together. As Pierre Chambat (1994) writes, the novelty of WhatsApp's pedagogical uses in this context did not operate in a social vacuum but was buckled onto previous practices adapted to new needs.

While this mixing of modalities is theoretically interesting in terms of the sociology of uses (Chambat 1994), ${ }^{30}$ it has nonetheless raised pedagogical concerns. In the opinion of RP 3, Cameroonian students experienced two significant difficulties in their distance learning during COVID-19: lack of access to institutional platforms, and poor organisation of files and messages on WhatsApp. Regarding the latter difficulty, this resource person commented: "Several teachers have told me that many university students find it challenging to track the progress of their learning from WhatsApp exchanges" (RP 3). In a similar vein, RP 4 also pointed to organisational deficits as one of the difficulties encountered by Cameroonian students in their distance learning throughout COVID-19. These organisational deficits refer to a disorderly management of time, resources, files, learning activities, course chapters and teamwork. Besides, as Philippe Perrenoud remarked two decades ago, learning is fundamentally about organisation, order and relationship. The "modular architecture of the curriculum" (Perrenoud 1999, p. 533) is what guides classwork and sets

\footnotetext{
${ }^{29}$ NEO is a cloud-based learning management system (LMS); an online learning platform for schools and universities.

${ }^{30}$ The "sociology of uses" (sociologie des usages) refers to the study of social uses of ICTs in France, which began in the 1980s.
} 
priorities (Perrenoud 1997). In an article entitled "What is learning?" Perrenoud argues that transmitting knowledge is enabling others to reorganise it (Perrenoud 2003).

Insufficient mastery of distance learning devices therefore favoured the use of WhatsApp and smartphones to ensure course continuity in Cameroonian universities. Despite the creation of course-specific groups, this led to a mix between educational content and private conversations which detracted from learning. In this hybrid environment, it was difficult for many students to organise their coursework and track their progress.

\section{Use of technology reveals the shortcomings of the education system}

In terms of technical socialisation, I have shown elsewhere (Béché 2017a) that the use of technologies in a particular context reveals and reflects the reality of that context. Blaise Gnimassoun and Sampawende Jules Tapsoba (2020) also argue that the pandemic highlights the structural weaknesses of African states, especially in the areas of economy, health and education. These weaknesses include the absence of an e-learning policy, the presence of social inequalities, and the inadequate technopedagogical equipment of institutions, teachers and learners.

Although the Education Orientation Law (GoRC 1998) and the Higher Education Law (GoRC 2001) both state that education must adapt to the technological evolution of the world, distance education currently features only as an alternative to face-to-face teaching. Policies of online training development do not yet exist in any of the ministries in charge of education in Cameroon. The codification of distance education, in which I am involved, is still undergoing consultation in the Ministry of Higher Education. Pending the creation of technological development centres at university level within the framework of the E-National Higher Education Network project, ${ }^{31}$ there is currently no structure in place yet which would be capable of supporting digital training in Cameroon.

Local educational institutions such as universities, high schools and colleges lack a techno-pedagogical development plan, even if e-learning is organised sporadically (Mequanint and Lemma 2014). This lack of political orientation and techno-pedagogical structures should not be confused, however, with the emergence of individual initiatives and dynamics, albeit poorly coordinated and institutionalised. As I showed in an article sketching the implementation of distance learning at the Higher Teachers Training College of Maroua (Béché 2017b), these emerging training modes result from reflections carried by individuals, but encounter a kind of "glass ceiling" at the level of political decision-making. Until the arrival of COVID-19,

\footnotetext{
31 The E-National Higher Education Network project was initiated by Cameroon's President, Paul Biya, in June 2015. It is based on a Framework agreement for economic and cultural cooperation between the Republic of Cameroon and the People's Republic of China (Li et al. 2017, p. 46). The project "provides for the construction of ten (10) University digital development centres (UDDCs), one per state university, one centre for the Cameroon-Congo inter-states university in Sangmelima, and another centre for the coordination of the entire network (ibid., p. 45).
} 
schools in Cameroon had not fully grasped the new modes of access to information and the new ways of teaching and learning which these enable (Meirieu 2020).

While the arrival of COVID-19 exposed the shortcomings of educational structures in Cameroon, the tools employed to ensure pedagogical continuity also revealed that the development of distance education systems is a vital necessity for education. The implementation of these tools has shown that the development of techno-pedagogical skills among teachers and students is not just a fad, ${ }^{32}$ but an essential resource for ensuring quality education, both in crises and in "normal" times. Educational structures have proven unable to adapt sufficiently quickly to the COVID-19 emergency to ensure the normal functioning of education throughout the pandemic. One of the reasons for this is that before COVID-19, distance education received little institutional attention, despite the flaunting of techno-pedagogical innovations since 2001-2002 (Béché 2017b).

The amount of time which elapsed between the first confirmed case of COVID19 in Cameroon (6 March 2020) and the launch of distance schooling (6 April) reflects the chaos and shock experienced in the field of education. Similarly, the approximation and improvisation seen in the search for pedagogical continuity solutions revealed an education system that was unprepared to switch from face-to-face to distance education. Admittedly, the extent of the health crisis was unforeseeable. However, the system was in its pedagogical and structural infancy due to the low level of technological development in the country as a whole and in schools in particular. Besides these difficulties with distance learning, the crisis has also revealed that a number of vital utility services, such as electricity and the internet, and electronic devices, such as computers and mobile phones, are not accessible to most of the population. This lack of access to essential services and equipment also limits access to training methods based on the use of new technologies.

The Cameroonian Education Orientation Law states that "the State ensures the right of the child to education ... [and] guarantees equal opportunities for access to education for all" (GoRC 1998, Arts. 6, 7). However, the COVID-19 crisis has shown that, in practice, not all pupils and students in Cameroon have the same access to schooling. "School on TV", for example, excluded almost $48 \%$ of children, especially those in rural areas without electricity, those in areas not covered by the CRTV signal, and those in families without television sets (Mbodiam 2019). Similarly, the children of those $70 \%$ of Cameroonians who lack an internet connection were also excluded from access to the digital educational resources provided on the websites of the Ministries of Secondary Education and Basic Education. In higher education, where training during lockdown has been mainly online, access to education has also not been at the same level for all students. Even if, as indicated by Mbodiam (2020), more than 59\% of Cameroonian internet users, mostly young people, including university students, own a smartphone, RP 3 and RP 4 estimated that only $12 \%$ have a high-quality smartphone. As RP 3 pointed out, "students are not all in the same boat; there are smartphones and smartphones". For him, "many students have experienced ergonomic difficulties, gaps in the use of applications, and

\footnotetext{
32 A fad is a short-lived intense enthusiasm for something.
} 
problems displaying data on smartphones" (RP 3). Those without a reliable internet connection and/or a computer do not have the same ease in switching to online courses as those with better access to technology.

To sum up, the response of the Cameroonian education sector to COVID-19 has exposed its fragility and inadequacy on a number of levels. Pedagogical continuity solutions took too long to implement and were insufficiently proactive, due to inadequate integration of distance technologies in schools and low access to essential socio-educational services. The most significant weakness revealed in my findings is the exceedingly high level of educational exclusion and inequality.

\section{Conclusion}

In this article, I have reviewed the Cameroonian responses to the effects of COVID19 on the education sector. With schools and campuses locked down, these have included "School on TV", radio education and online database resources for primary and secondary education. Higher education courses were delivered through learning management systems, WhatsApp, Google Classroom, Skype, Zoom, e-mail and mobile phones. Alongside these primary institutional responses, individual and community initiatives have also flourished, with free digital resources being offered by both institutions and individuals.

My analysis of these responses has revealed pedagogical chaos, which, coupled with technical improvisation, has led to educational disarray. I have noted the isolated and pre-governmental initiative of the University of Yaounde 1 and the long period of time that elapsed between the onset of the crisis and the reaction of the ministries in charge of education. I have also highlighted the dithering and confusion that characterised the search for model lessons and solutions to ensure pedagogical continuity. The education system was shown to be unprepared for the shift from face-to-face to distance education, obliging individuals and communities to step into the gap left by an uncoordinated governmental and institutional response. Hence the multiplicity of competence centres which gave the impression that "any action was welcome to address the crisis" and that it was "going every which way".

The implementation of these various responses has created an unprecedented pedagogical environment. Institutional and community initiatives, official and unofficial tools, and digital and hard supports have coexisted side-by-side, creating a confusing array of options. In WhatsApp groups, I observed a kind of hybridisation between educational content and conversations from private or everyday life. The new pedagogical continuity tools, particularly "School on TV", have made fundamental changes to the social character of the educational environment. Perhaps most significantly, computer experts have stepped into the central role previously occupied by teachers. Whilst they have performed some functions usually carried out by teachers, such as the dissemination of teaching content, they did not possess a teacher's pedagogical know-how. Distance learning was therefore characterised by pedagogical disorganisation on WhatsApp and a weakening of teacher-learner interactions in favour of file uploading on platforms. Screens and IT experts have played an integral part in pedagogical mediation. 
The COVID-19 crisis has also laid bare the educational inequalities long hidden behind the high enrolment rates so often boasted about. Several categories of learners were excluded from distance education. Those unlucky enough to be in intermediate classes, rural areas, or areas not covered by electricity or the CRTV signal became the "forgotten ones" of distance schooling. Many more learners were still disadvantaged despite officially being "schooled" due to a lack of human or digital assistance at home, be it inadequate parental support, intermittent internet access, or poor computer skills.

This evaluation of Cameroonian educational responses to COVID-19 highlights two issues in particular that education policymakers should insist upon to ensure uninterrupted training delivery in the event of other similar crises. The first is the long overdue development of distance education, which has existed in some form for 30 years already. The second, related issue concerns the generalisation of access to essential services such as electricity, television and the internet, without which the development of distance learning would be impossible. The expansion of distance learning must focus on three points: (1) equipping schools and teachers with the necessary technological infrastructure and devices; (2) training teachers and learners to use the equipment effectively; (3) and integrating it creatively into the fabric of school life. The COVID-19 pandemic has shown that these factors are vital to the continued delivery of quality education in the event of a crisis. As a suggestion for further research, it would be interesting to investigate how much progress has been made on these issues since Cameroonian schools returned to near-normality on 1 June 2020.

Acknowledgements I would like to thank the Pilot Africa Postgraduate Academy (PAPA) programme, of which I am a fellow, for providing technical and financial support towards conducting this study. PAPA is funded by Goethe University Frankfurt in Germany.

\section{References}

Adjouda, E. (2020). Cameroun-COVID-19 et silence présidentiel: le militant et cadre du RDPC Saint Eloi Bidoung, crache 4 vérités à Paul Biya [Cameroon-COVID-19 and presidential silence: CPDM (Cameroon People's Democratic Movement) militant and leader Saint Eloi Bidoung spits out 4 truths to Paul Biya]. 237actu.com, 8 April. Retrieved 7 July 2020 from https://237actu.com/camer oun-covid-19-et-silence-presidentielle-le-militant-et-cadre-du-rdpc-saint-eloi-bidoung-crache-4verites-a-paul-biya.

Andrianarison, F., \& Nguem, B. E. (2020). Effets socioéconomiques potentiels du COVID-19 au Cameroun: Une évaluation sommaire [Potential socio-economic effects of COVID-19 in Cameroon: A summary evaluation]. New York, NY: United Nations Development Programme (UNDP). Retrieved 15 September 2020 from https://www.undp.org/content/dam/rba/docs/COVID-19-CO-Response/ Socio-Economic-Impact-COVID-19-Cameroon-UNDP-Cameroon-March-2020.pdf.

Azzi-Huck, K., \& Shmis, T. (2020). Managing the impact of COVID-19 on education systems around the world: How countries are preparing, coping, and planning for recovery. World Bank Blogs, 18 March [blog post]. Retrieved 9 May 2020 from https://blogs.worldbank.org/education/managingimpact-covid-19-education-systems-around-world-how-countries-are-preparing.

Bahia, K., \& Suardi, S. (2019). Connected society: The state of mobile internet connectivity. Annual Report. London: Global System for Mobile Communications (GSM) Association. Retrieved 19 May 2020 from https://www.gsma.com/mobilefordevelopment/wp-content/uploads/2019/07/GSMAState-of-Mobile-Internet-Connectivity-Report-2019.pdf. 
Balle, F. (1994). L'école et la télévision [Schools and television]. Communication et Langages, 100101, 79-88. https://doi.org/10.3406/colan.1994.2515.

Barba, D. (2020). L'école à la télé : France 4 se transforme en salle de classe. Franceinter/Radio France, 22 March [webnews item]. Retrieved 8 October 2020 from https://www.franceinter.fr/ emissions/barbatrucs/barbatrucs-23-mars-2020.

Béché, E. (2017a). Étudier l'appropriation des TIC à l'école en combinant l'examen des usages et des représentations sociales des utilisateurs. Une analyse à partir du contexte d'intégration de l'ordinateur et l'Internet dans quatre lycées de Yaoundé (Cameroun) [Studying the appropriation of ICTs at school by combining the examination of uses and the social representations of users: An analysis based on the context of the integration of computers and the internet in four high schools in Yaoundé (Cameroon)]. tic\&société, 10(2-3), 269-302. https://doi.org/10.4000/ ticetsociete. 2108 .

Béché, E. (2017b). Conceptualizing the implementation of distance learning system at the Higher Teacher's Training College of Maroua (Cameroon). International Journal of Humanities Social Sciences and Education, 4(5), 51-62.

Bellen, L. (2016). Play - lost in transition? Teacher beliefs about pedagogic continuity across the transition to formal schooling. PhD dissertation. School of education. Fremantle, WA: The University of Notre Dame Australia. Retrieved 15 September 2020 from https://core.ac.uk/downl $\mathrm{oad} / \mathrm{pdf} / 84689514 . \mathrm{pdf}$.

Bianchini, P. (2004). École et politique en Afrique noire. Sociologie des crises et des réformes du système d'enseignement au Sénégal et au Burkina Faso (1960-2000) [School and politics in subSaharan Africa: Sociology of crises and reforms of the education system in Senegal and Burkina Faso (1960-2000)]. Paris: Karthala.

CamerounWeb. (2020). Coronavirus: L'université de Yaoundé 1 suspend ses cours [Coronavirus: University of Yaoundé 1 suspends its courses]. CamerounWeb, 16 March [online news item]. Retrieved 7 July 2020 from https://www.camerounweb.com/CameroonHomePage/NewsArchive/ Coronavirus-1-universit-de-Yaound-1-suspend-ses-cours-498841.

Chambat, P. (1994). Usages des technologies de l'information et de la communication (TIC): évolution des problématiques [Uses of information and communication technologies (ICTs): Changing issues]. Technologies de l'Information et Société, 3(6), 249-270.

Coronavirus Statistiques. (2020). Coronavirus (COVID-19) statistiques au Cameroun: Évolution du nombre de cas et de contaminations jour par jour (Coronavirus statistiques en ligne) [Coronavirus (COVID-19) statistics in Cameroon: Evolution of the number of cases and contaminations day by day (online Coronavirus statistics)]. Paris: Eficiens. Retrieved 10 July 2020 from https:// www.coronavirus-statistiques.com/stats-pays/coronavirus-nombre-de-cas-au-cameroun/.

CRTV (Cameroon Radio Television). (2020a). Le numérique peut-il assurer la continuité des cours à l'université. Entretien réalisé avec Jacques Fame Ndongo le 20 mars 2020 [Can digital technology ensure the continuity of courses at university? Interview with Cameroonian minister of higher education Jacques Fame Ndongo on 20 March 2020]. Cameroon Radio Television, 20 March [TV interview]. Retrieved 10 July 2020 from the Mediatude Facebook page: https://www. facebook.com/watch/?v=225383921989123.

CRTV. (2020b). Le journal télévisé (JT) du $20 h 30$ [The news at 8.30 p.m.] JT, 20 March [TV news broadcast]. Retrieved 10 July 2020 from http://www.crtv.cm/2020/03/le-jt-de-20h30 -20-mars-2020/.

De Ketele, J. M. (1992). L'évaluation: Approche descriptive ou prescriptive? [Evaluation: Descriptive or prescriptive approach?]. Brussels: De Boeck.

Djimadeu, C. (2020). Cameroun-Covid-19 : la CRTV lance « l'école à la télé » le 6 avril [Cameroon COVID-19: Cameroon Radio Television launches "School on TV" on 6 April]. Journal du Cameroun, 6 April [webnews item]. Retrieved 6 October 2020 from https://www.journalducameroun.com/ cameroun-covid-19-le-crtv-lance-lecole-a-la-tele-ce-6-avril/.

Doury, M. (2013). Positionnement descriptif, positionnement normatif, positionnement militant [Descriptive positioning, normative positioning, militant positioning]. Argumentation et Analyse du Discours, 11, Art. 5. https://doi.org/10.4000/aad.1540.

DSDEN de 1'Oise. (2020). Continuité pédagogique - circonscription de Grandvilliers, Académie Amiens [Pedagogical continuity - Grandvilliers district, Amiens Academy] [dedicated webpage]. Amiens: Direction des Services Départementaux de l'Éducation Nationale [Departmental Services Directorate of National Education]. Retrieved 19 May 2020 from http://grandvilliers.dsden60.ac-amiens.fr/ Continuite-pedagogique.html. 
Gaetan, P. (2020). France: pedagogical continuity - chaos in national education. International Marxist Tendency (IMT). In Defence of Marxism, 14 April [online article]. Retrieved 12 June 2020 from https://www.marxist.com/france-pedagogical-continuity-chaos-in-national-education.htm.

Gnimassoun, B., \& Tapsoba, S. J. (2020). Après-Covid-19: Une occasion historique de réinventer le développement de l'Afrique [Post-COVID-19: An historic opportunity to reinvent Africa's development]. Le Point, 9 June [online article]. Retrieved 19 June 2020 from https://www.lepoint.fr/afrique/ apres-covid-19-une-occasion-historique-de-reinventer-le-developpement-de-1-afrique-09-06-20202379032_3826.php.

GoRC (Government of the Republic of Cameroon). (1998). LOI N98/004 du 4 avril 1998 d'orientation de l'éducation au Cameroun1 [Law No. 98/004 of 4 April 1998 on the orientation of Education in Cameroon]. Yaoundé: Government of the Republic of Cameroon. Retrieved 14 July 2020 from http://www.unesco.org/education/edurights/media/docs/3fbc027088867a9096e8c86f0169d457b2c a7779.pdf.

GoRC. (2001). LOI N 005 du 16 avril 2001 Portant orientation de l'Enseignement Supérieur [Law No. 005 of 16 April 2001 on the orientation of Higher Education in Cameroon]. Yaoundé: Government of the Republic of Cameroon. Retrieved 14 July 2020 from http://www.unesco.org/education/eduri ghts/media/docs/073d65dfde800ba6e9e8e8c72db5dcc48abaa500.pdf.

IGE (Inspection Générale des Enseignements) [Inspectorate General of Education]. (2020). Lutte contre le Coronavirus [Fight against Coronavirus]. Memorandum to teachers, $n^{\circ}$ 074/20/MINESEC/IDE of 18 March. Yaounde: Ministry of Secondary Education.

ITU (International Telecommunication Union). (2019). Measuring digital development: Facts and figures 2019. Geneva: ITU. Retrieved 19 October 2020 from https://www.itu.int/en/ITU-D/Statistics/ Documents/facts/FactsFigures2019.pdf.

Kana, C. -E. (2019). L'inadéquation entre l'offre et la demande d'éducation au Cameroun: Le cas du Département du Logone-et-Chari [The mismatch between supply and demand for education in Cameroon: The case of the Logone-et-Chari Subdivision]. Recherches \& Éducations, Varia [online]. https://doi.org/10.4000/rechercheseducations.7133.

Li, M., Bi, X., Li, X., Song, H., \& Zhu, K. (Eds). (2017). Synthesis report of seminar on ICT in higher education innovation for African countries 2017: Botswana, Cameroon, Djibouti, Egypt, Ethiopia, Ghana, Malawi. Shenzhen: UNESCO International Centre for Higher Education Innovation (UNESCO-ICHEI). Retrieved 8 October 2020 from http://en.ichei.org/uploads/2018/08/Synthesis-Repor t-of-Seminar-on-ICT-in-Higher-Education-Innovation-for-African-Countries-2017.pdf.

Lum, P. (2020). COVID-19: CRTV sets up distance learning to help students. Cameroon Radio Television (CRTV), 9 April [online article]. Retrieved 6 October 2020 from http://www.crtv.cm/2020/04/ covid-19-crtv-sets-up-distance-learning-to-help-students/.

Mbodiam B. R. (2019). Énergie: Malgré la hausse constante de la demande, le taux d'accès à l'électricité au Cameroun croît de 4\% entre 2015 et 2017. [Energy: Despite the constant increase in demand, the rate of access to electricity in Cameroon grew by 4\% between 2015 and 2017]. Investir au Cameroun, 29 October [online article]. Retrieved 8 July 2020 from https://www.investiraucameroun.com/ energie/2910-13476-malgre-la-hausse-constante-de-la-demande-le-taux-d-acces-a-l-electricite-aucameroun-croit-de-4-entre-2015-et-2017.

Mbodiam, B. R. (2020). Économie: Le taux de pénétration de l'internet au Cameroun atteint 30\% en 2020, grâce à l'arrivée de 570000 nouveaux internautes Economy: Internet penetration rate in Cameroon reaches $30 \%$ in 2020 , thanks to the arrival of 570,000 new internet users]. Inverstir au Cameroun, 24 February [online article]. Retrieved 7 July 2020 from https://www.investiraucameroun.com/ economie/2402-14084-le-taux-de-penetration-de-1-internet-au-cameroun-atteint-30-en-2020-grace -a-1-arrivee-de-570-000-nouveaux-internautes.

Meirieu, P. (2020). École à distance: une fracture éducative? Émission "Décryptage" avec Éric Charbonnier du 26 avril 2020 [Distance learning: an educational divide? "Deciphering" programme presented by Éric Charbonnier]. Radio France International, 26 April [radio broadcast]. Retrieved 24 May 2020 from http://www.rfi.fr/fr/podcasts/20200427-\%C3\%A9cole-\%C3\%A0-distance-une-fract ure-\%C3\%A9ducative.

Mequanint, D., \& Lemma, D. (2014). L’intégration des TIC en pédagogie dans les pays en voie de développement: le cas de l'Éthiopie [Integrating ICT pedagogy in developing countries: the case of Ethiopia]. Revue Internationale d'Éducation de Sèvres, 67, 75-84. https://doi.org/10.4000/ries.4117.

MINEDUB (Ministère de l'Éducation de Base/Ministry of Basic Education). (2018). La situation de l'éducation au Cameroun [The education situation in Cameroon] WATHI, 25 September [dedicated webpage]. Dakar: West Africa Think Tank (WATHI). Retrieved 3 June 2020 from https://www. 
wathi.org/election-cameroun-2018/contexte-election-cameroun-2018/la-situation-de-leducation-aucameroun/.

MINEDUB (Ministère de l'Éducation de Base/Ministry of Basic Education). (2020). Circulaire du 31 Mars 2020 relative à l'apprentissage continu des élèves [Circular of 31 March 2020 related to the continuous learning of students]. Circular letter, $\mathrm{n}^{\circ}$ 010/B1/1464/LC/MINEDUB/IEG. Yaoundè: MINEDUB. Retrieved 18 October 2020 from http://www.minedub.cm/index.php?id=253.

MINESEC (Ministère des Enseignements Secondaires/Ministry of Secondary Education). (2020). Mémorandum sur le «Contenu de l'enseignement à distance » [Memorandum on "Content of distance education", issued by the Minister for Secondary Education]. Note n ${ }^{\circ}$ 384/20/L/MINESEC/ CAB, 19 March. Yaoundé: MINESEC.

MINESUP (Ministère de l'Enseignement Supérieur/Ministry of Higher Education). The Ministry of Higher Education's strategy against coronavirus: Press release. Yaoundé: MINESUP. Retrieved 6 October 2020 from http://www.minesup.gov.cm/site/2020/Ministre/Communique\%20final\%20COV ID\%2019_MINESUP_en.pdf.

Mouafo Djontu, H. (2013). La notion de zones d'éducation prioritaires (ZEP) au Cameroun: Entre impensé, bricolage et informalité [The notion of Priority Education Zones (ZEP) in Cameroon: Between the unthinkable, do-it-yourself and informality]. Irenees.net, November [online article]. Retrieved 10 July 2020 from http://www.irenees.net/bdf_fiche-analyse-1004_fr.html.

Onana, A. (2020). Cameroun: Les délestages atteignent la côte d'alerte: Cameroon [Cameroon: Loadshedding reaches high alert]. Camer.be, 19 February [online article]. Retrieved 7 July 2020 from https://www.camer.be/79088/11:1/cameroun-les-delestages-atteignent-la-cote-dalerte-cameroon. html.

Peraya, D. (2008). Lecture critique. La formation à distance dans les pays du Sud. Paroles et témoignages d'acteurs. De Jacques Guidon et Jacques Wallet (dir). Formation à distance en Afrique subsaharienne. Études comparées [Book review: J. Guidon and J. Wallet (eds), Distance learning in Southern countries: Words and testimonies of actors, edited by Jacques Guidon et Jacques Wallet]. Distances et Savoirs, 6(4), 629-634.

Perrenoud, P. (1997). Organiser et animer des situations d'apprentissage [Organising and facilitating learning situations]. l'Éducateur, 11, 26-33.

Perrenoud, P. (1999). De la gestion de classe à l'organisation du travail dans un cycle d'apprentissage [From classroom management to the organisation of work in a learning cycle]. Revue des sciences de l'éducation, 25(3), 533-570. https://doi.org/10.7202/032013ar.

Perrenoud, P. (2003). Qu'est-ce qu'apprendre? [What is learning?]. Enfances \& Psy, 4(24), 9-17. https:// doi.org/10.3917/ep.024.0009.

RFI (Radio France Internationale). (2020). Relief for French parents as public television to broadcast school lessons. RFI, 21 March [webnews item]. Retrieved 8 October 2020 from https://www.rfi. fr/en/france/20200321-france-20200321-relief-for-french-parents-as-public-television-to-broadcastschool-lessons-coronavirus-lockdown-france-4-covid-19.

Routley, N. (2020). Where COVID-19 is rising and falling around the world. Visual Capitalist, 12 May [online article]. Retrieved 21 May 2020 from https://www.visualcapitalist.com/where-covid-19-isrising-and-falling-around-the-world/.

Søndergaard, B. (1995). Problems of pedagogical continuity within a minority. European Education, 27(3), 53-61. https://doi.org/10.2753/EUE1056-4934270353.

SPM (Services du Premier Ministre du Cameroun/Office of the Prime Minister of Cameroon). (2020). Stratégie gouvernementale de riposte contre la pandémie du Coronavirus (COVID-19). Déclaration spéciale du Premier Ministre, Chef du Gouvernement [Government strategy for responding to the Coronavirus Pandemic (COVID-19). Special Statement by the Prime Minister, Head of Government]. Transcript of a radio press release. Yaoundé: Office of the Prime Minister of Cameroon Retrieved 17 October 2020 from https://www.spm.gov.cm/site/sites/default/files/declaration_speci ale_du_pmcg_riposte_face_a_la_pandemie_du_covid-19.pdf.

UIS (UNESCO Institute for Statistics). (2020). Education and literacy - Cameroon [online resource]. Montreal: UIS. Retrieved 16 October 2020 from http://uis.unesco.org/en/country/cm?theme=educa tion-and-literacy.

UNESCO (United Nations Educational, Scientific and Cultural Organization). (2020). Impact du Covid19 sur le système éducatif du Cameroun [Impact of COVID-19 on Cameroon's education system]. UNESCO news, 25 March [webnews]. Retrieved 21 April 2020 from https://fr.unesco.org/news/ impact-du-covid-19-systeme-educatif-du-cameroun. 
UNSDG (United Nations Sustainable Development Group). (2020). Plan de réponses socio-économiques des NU contre la COVID-19 [United Nations COVID-19 socio-economic response plan for Cameroon]. Youndé: United Nations Cameroon. Retrieved 16 October 2020 from https://unsdg.un.org/ resources/united-nations-covid-19-socio-economic-response-plan-cameroon.

Publisher's Note Springer Nature remains neutral with regard to jurisdictional claims in published maps and institutional affiliations.

Emmanuel Béché PhD, is an Associate Professor of Sociology of Educational Technology at the University of Maroua, Cameroon. At the heart of his research lies the study of the implementation of technological innovations and the use of electronic devices at school. Dr Béché has received several research grants, accepted invitations to about ten research stays abroad and participated in academic exchange programmes. He is currently a Fellow of the Pilot African Postgraduate Academy (PAPA) programme. 